\title{
Cellular and Humoral Mechanisms of Immune Tolerance in Immediate-Type Allergy Induced by Specific Immunotherapy
}

\author{
Christian Möbs $^{\mathrm{a}}$ Caroline Slotosch $^{\mathrm{a}}$ Harald Löffler ${ }^{\mathrm{a}, \mathrm{b}}$ Wolfgang Pfützner ${ }^{\mathrm{a}}$ \\ Michael Hertla \\ ${ }^{a}$ Department of Dermatology and Allergology, Philipps University, Marburg, and ${ }^{\mathrm{b}}$ Department of Dermatology, \\ SLK Clinics, Heilbronn, Germany
}

\section{Key Words}

Immediate-type allergy · Specific immunotherapy •

Regulatory T cell $\cdot$ Immunoglobulin $\mathrm{E} \cdot$ Immunoglobulin $\mathrm{G} 4$

\section{Abstract}

The management of immediate-type allergy (ITA) is based on allergen avoidance, symptomatic pharmacological therapy and specific immunotherapy (SIT). Among these, SIT presents the only curative treatment. The efficacy of SIT in the treatment of IgE-mediated ITA has been proven in numerous clinical studies and is well established. This review discusses the relevance of immunoregulative humoral and cellular mechanisms leading to immune tolerance in ITA. Special focus is placed on the role of antibodies potentially interfering with the lgE-mediated immune reaction and regulatory $T\left(T_{\text {reg }}\right)$ cells including their immunosuppressive cytokines, which play a critical role in shifting the $T$ helper 2 cell-driven allergic immune response towards allergen tolerance. Distinct subsets of constitutive and inducible $T_{\text {reg }}$ cells have been identified inhibiting the activation of allergenspecific effector T cells via cell contact- or cytokine-dependent suppression. Current research suggests that both inducible interleukin-10-producing $C D 4+\mathrm{T}_{\text {reg }}$ cells and naturally occurring $C D 4+C D 25+T_{\text {reg }}$ cells actively control allergic responses and that the disturbance of their function or number may contribute to the development or progression of allergy. Thus, the fine balance between allergen-specific $T$ helper 2 and $T_{\text {reg }}$ cells constitutes a critical factor for the successful treatment of ITA by SIT.

Copyright $\odot 2008$ S. Karger AG, Basel

For a long time, specific immunotherapy (SIT), the only approved curative treatment capable of modifying the natural history of individuals suffering from immediate-type allergy (ITA), was based merely on experience. Pioneered by Noon and Freeman almost a century ago, who treated patients suffering from allergic rhinoconjunctivitis with a low-dose incremental schedule of pollen injections [1], the basic principles of SIT have stayed the same. In 1998, the WHO accepted the therapeutic benefit of SIT [2], and recommendations were published regarding the mode of application and the modalities of SIT treatment. Until now, the effects of SIT have been documented in numerous controlled clinical studies with different allergens, such as birch and grass pollen [3, 4]. Only recently, the cellular and molecular mechanisms of SIT became more and more the objective of research studies.

\section{KARGER \\ Fax +41613061234 \\ E-Mail karger@karger.ch}

www.karger.com (c) 2008 S. Karger AG, Basel

$1018-2438 / 08 / 1473-0171 \$ 24.50 / 0$

Accessible online at:

www.karger.com/iaa
Correspondence to: Christian Möbs

Department of Dermatology and Allergology

Philipps University Marburg

Deutschhausstrasse 9, DE-35037 Marburg (Germany)

Tel. +49 6421286 5718, Fax +496421 286 5729, E-Mail moebs@med.uni-marburg.de 


\section{Immediate-Type Allergy}

ITA, classified as type 1 allergy by Coombs and Gell [5], is characterized by the production of allergen-specific IgE antibodies. The initial step in the development of ITA is the priming of allergen-specific CD4+ T helper 2 (Th2) cells [6]. Production of Th2 cell cytokines, such as interleukin (IL)-4, IL-5, IL-9 and IL-13, is essential in this process since $\mathrm{T}$ cell activation in the presence of IL-4 increases the differentiation of naive $\mathrm{T}$ cells into Th2 cells [7-9]. In addition, the secretion of IL- 4 and IL-13 by Th2 cells in the presence of allergen recognized by naive $B$ cells leads to the synthesis and secretion of allergen-specific IgE by plasma cells [10]. The central role of IgE antibodies in ITA such as allergic rhinoconjunctivitis, asthma or anaphylaxis is well known. Cross-linking of $\operatorname{IgE}$ receptors on the surface of effector cells such as basophils and mast cells by complexes of IgE antibodies and captured allergen results in an immediate-type immune reaction characterized by the release of histamine and the synthesis of prostaglandins, leukotrienes, proinflammatory cytokines and other mediators of the allergic response.

\section{SIT: Humoral Mechanisms}

During the course of SIT, a progressive decrease in allergen-specific IgE serum levels (following an initial transient increase) to preimmunotherapy levels or lower [11, 12] as well as moderate or no alterations in allergen-specific IgE antibody titers can be observed $[13,14]$.

\section{Allergen-Specific IgG Antibodies}

Apart from changes in IgE levels, an increase in allergen-specific IgG antibodies has been reported [13, 15]. These antibodies can block IgE-mediated anaphylaxis in vivo and seem to inhibit not only the allergen-induced release of inflammatory mediators from basophils and mast cells, but also IgE-mediated allergen-presentation to T cells [16].

Among the SIT-induced IgG antibodies, allergen-specific IgG4 has been proposed to play an important 'protective' role, since it competes with allergen-specific IgE antibodies for binding to administered allergen and can prevent the activation of $\mathrm{CD} 4+\mathrm{T}$ cells by inhibition of IgE-mediated antigen presentation [17-19]. Furthermore, the IgG4 subset, which is secreted in significant quantities after prolonged SIT and remains stable during long intervals of continued immunotherapy $[20,21]$, promotes a significant reduction in mast cells and eosinophils accompanied by a diminished release of inflammatory mediators [22-24]. It was thus suggested, that increasing IgG4 antibody levels correlate with the clinical efficacy of SIT $[25,26]$ and may be considered as a marker of SITinduced immune tolerance and decreased allergen sensitivity $[2,15,27]$.

However, in a number of studies, subsets of patients with good clinical relief had no significant IgG antibody production, and some patients with increased IgG antibody titers showed no clinical response [28, 29], raising the possibility that the synthesis of IgG antibodies may rather reflect high allergen exposure than play a causal role in successful immunotherapy. Since there is a great interindividual variability in IgG4 levels among SITtreated allergic patients not strictly correlating with the clinical outcome of SIT [30], allergen-IgG/IgG4 antibody complexes are apparently controversially discussed in modulating the allergic immune response and preventing IgE-mediated reactions.

\section{Anti-IgE Antibodies}

With regard to allergen-specific antibody responses before and during SIT treatment, anti-IgE antibody therapy seems to be a complementary approach to treat allergic diseases. In light of recent demonstrations that binding of IgE to FceRI receptors on mast cells not only elicits an allergic effector phase but also contributes to an amplified allergic reaction by enhancing mast cell survival and FceRI expression [31, 32], the interaction between IgE and specific IgE receptors provides an attractive target for the inhibition of ITA. It has been shown that antiIgE antibodies are able to interfere with $\operatorname{IgE}$ binding to FceRI receptors by capturing free serum IgE, thus resulting in reduced leukotriene release after stimulating mast cells with allergen $[33,34]$. Taken together, anti-IgE monoclonal antibody therapy represents an effective approach to treat ITA, which can be implemented as a monotherapy as well as in combination with SIT [35, 36].

\section{SIT: Cellular Mechanisms}

SIT affects different components of the immune system (fig. 1). Cellular modifications consist of a reduction in allergen-induced $\mathrm{T}$ cell proliferation, indicating the induction of peripheral tolerance in allergen-specific $\mathrm{T}$ cells, and a decrease in the initially disease-eliciting, antigen-specific Th2-dominated immune response towards 


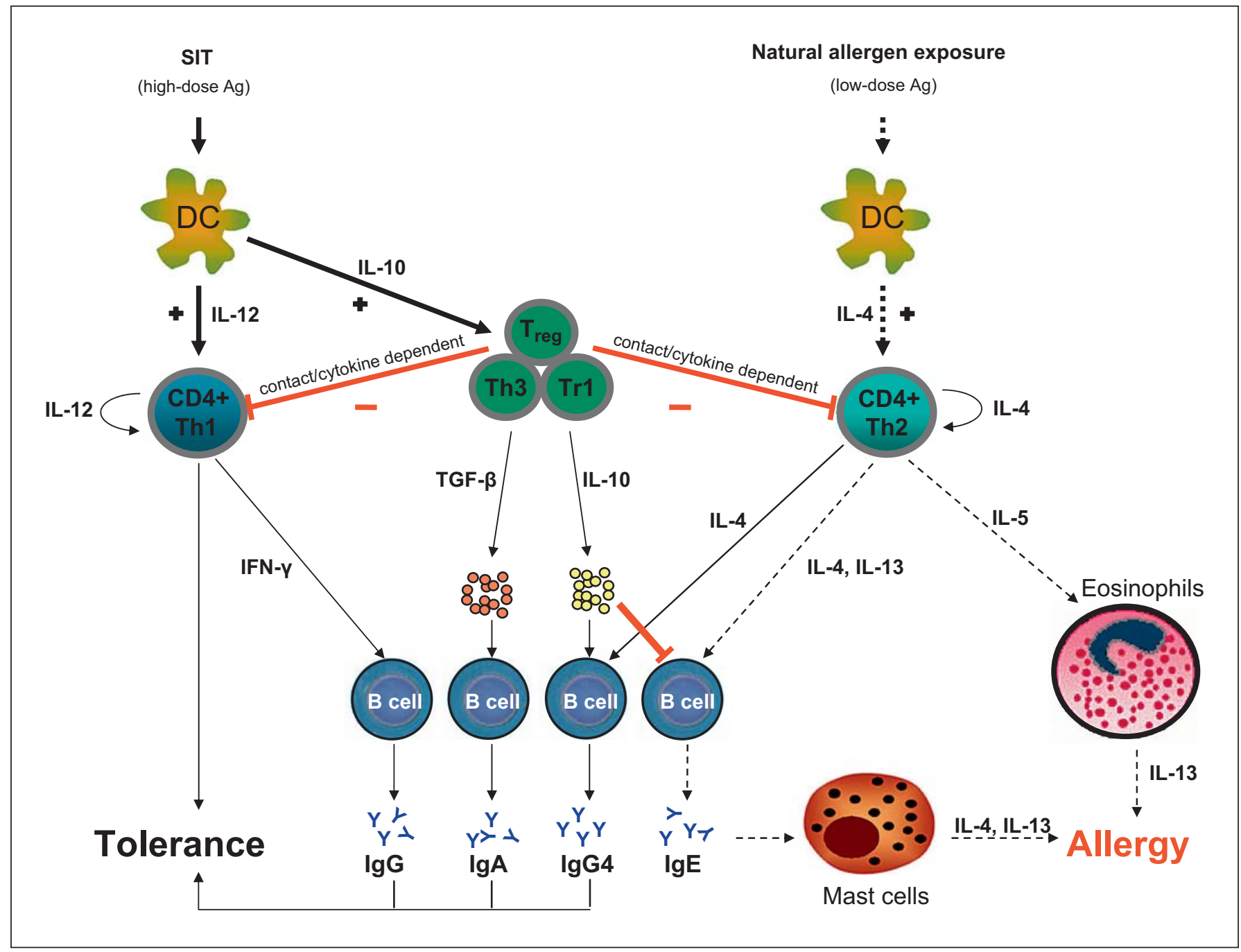

Fig. 1. Cellular and humoral network in ITA and tolerance induction by SIT. Upon SIT, different subsets of $\mathrm{T}_{\text {reg }}$ cells are activated by antigen-presenting dendritic cells (DC). Action of both naturally occurring $\mathrm{T}_{\text {reg }}$ cells $\left(\mathrm{T}_{\text {reg }}\right)$ and induced $\mathrm{T}_{\text {reg }}$ cells $(\mathrm{Tr} 1, \mathrm{Th} 3)$ influences the pattern of antibody synthesis by $\mathrm{B}$ cells and cyto- kine expression by T helper cells (Th1 and Th2) through cell-cell contact and cytokine-dependent mechanisms. This results in inhibition of the effector cells of ITA, mast cells and eosinophils and leads to immune tolerance. $\mathrm{Ag}=$ Allergen; IFN = interferon. a Th1 reaction with increased interferon- $\gamma$ production $[37,38]$. The key cell type responsible for orchestrating this switch of $\mathrm{T}$ cell activity is a $\mathrm{T}$ cell population called $\mathrm{T}_{\text {reg }}$ cells.

\section{$T_{\text {reg Cells }}$}

In healthy individuals, $\mathrm{T}_{\text {reg }}$ cells are usually present at a higher frequency than their effector counterparts [39]. They are able to inhibit the development of allergic Th2 responses [40], capable of directly suppressing the proliferation and cytokine expression of Th1 and Th2 cells, and exhibit inhibitory activity on antigen-presenting cells such as dendritic cells and macrophages [41]. A wealth of studies indicate that the ratio of Th2 cells to $\mathrm{T}_{\text {reg }}$ cells seems to be decisive for the success of SIT $[15,39,42]$. As a result, the disturbed balance of $\mathrm{T}_{\text {reg }}$ and effector cells in allergic individuals is re-established. Several distinct subsets of $\mathrm{T}_{\text {reg }}$ cells have been identified based on phenotypic and functional markers (table 1). Recent evidence of the role of different $T_{\text {reg }}$ cell subsets in allergy will be discussed below. 
Table 1. T lymphocyte subsets and immune tolerance in ITA

\begin{tabular}{|c|c|c|c|c|c|}
\hline $\begin{array}{l}\text { T cell } \\
\text { subset }\end{array}$ & Origin & $\begin{array}{l}\text { Subset-specific } \\
\text { markers }\end{array}$ & $\begin{array}{l}\text { Foxp3 } \\
\text { expression }\end{array}$ & Mode of action & Cytokine secretion \\
\hline Th1 & periphery & CD $4+{ }^{1}$, T-bet & - & $\begin{array}{l}\text { promotes chronic inflammation and persistence of the effector } \\
\text { phase, antagonizes Th2 cells }\end{array}$ & IFN- $\gamma$, IL-12 \\
\hline Th2 & periphery & $\mathrm{CD} 4+{ }^{1}, \mathrm{GATA}-3$ & - & promotes allergy, antagonizes Th1 cells, induces IgE and IgG4 & IL-4, IL-5, IL-13 \\
\hline $\mathrm{T}_{\text {reg }}$ & thymus & $\mathrm{CD} 4+\mathrm{CD} 25+^{2}, \mathrm{GITR}$ & + & $\begin{array}{l}\text { contact dependent, maintenance of tolerance against allergens, } \\
\text { inhibits effector T cells }\end{array}$ & TGF- $\beta$, IL-10 1 low \\
\hline Th3 & periphery & $\mathrm{CD} 4+^{1}$ & ? & induces oral tolerance & TGF- $\beta$, IL- $10^{\text {low }}$, IL- $4^{\text {low }}$ \\
\hline
\end{tabular}

\section{Type $1 T_{\text {reg }}$ Cells}

On the cellular level, presumably, the most contributing factor to successful allergen immunotherapy is the peripheral induction of type $1 \mathrm{~T}_{\text {reg }}$ (Tr1) cells. This is an inducible subset of $\mathrm{T}_{\text {reg }}$ cells, which was first isolated after cloning human $\mathrm{T}$ cells activated with alloantigens in the presence of IL-10 [43]. The diversity of Tr1 cells compared with Th1 and Th2 cells is characterized by the production of high amounts of IL-10, with or without transforming growth factor (TGF)- $\beta$, interferon- $\gamma$ and IL-5, and low or no IL-2 and IL-4 $[43,44]$.

Current concepts evidenced the critical role of $\operatorname{Tr} 1$ cells in the maintenance of tolerance against allergens and in the modulation of allergic diseases due to the fact that skewing of allergen-specific $\mathrm{T}$ cells to a Trl cell-like phenotype seems to be a pivotal event in successful SIT. This contention goes along with findings that allergenspecific Th2 cells are also found in healthy individuals [45], but compared with allergic patients, are balanced by the dominant subset of Trl cells supporting a regulatory network which prevents initiation of clinical symptoms [39, 46, 47].

Functional studies of Trl cells specific to distinct antigens revealed that the modulation of Th1 and Th2 responses by Trl cells mostly depends on the secretion of the immunosuppressive cytokine, IL-10 [48-51]. IL-10 inhibits the proliferative response of peripheral $\mathrm{T}$ cells against distinct antigens [52] and plays a crucial role in the induction of $\mathrm{T}$ cell anergy by blocking $\mathrm{CD} 28$ tyrosine phosphorylation and CD28 binding to downstream signaling molecules [53]. In vitro, it facilitates the expression of the regulatory transcription factor Foxp3 under IL-4/ IL-12-neutralizing conditions [54]. Other important effects of IL-10 on ITA include the modulation of eosino- phil function [55] and the reduction in proinflammatory mediators released by mast cells [56]. Nevertheless, Trl cells may also directly influence the activity of allergen-specific $\mathrm{T}$ cells as demonstrated by birch pollen allergen (Bet $v$ 1)-specific IL-10-producing $\mathrm{T}_{\text {reg }}$ cells suppressing the proliferation of effector Th cell clones by cell-to-cell contact, independent of cytokine secretion [57].

\section{CD4 + CD25 $+T_{\text {reg }}$ Cells}

The major subset of $\mathrm{T}_{\text {reg }}$ cells is a subpopulation of $\mathrm{CD} 4+\mathrm{T}$ cells that constitutively express the activation marker CD25 ( $\alpha$-chain of the IL-2 receptor), referred to as 'naturally' occurring $\mathrm{T}_{\text {reg }}$ cells [58-61]. In addition to $\mathrm{CD} 25$, these cells are characterized by expression of the glucocorticoid-induced tumor necrosis factor receptor and the most definitive $\mathrm{T}_{\text {reg }}$ cell marker, the forkhead winged-helix transcriptional factor Box p3 (Foxp3) [59, 62-64]. A significant property of $\mathrm{CD} 4+\mathrm{CD} 25+\mathrm{T}_{\text {reg }}$ cells is their ability to convey suppressive activity to other CD4+ T cells, a phenomenon termed infectious tolerance' [65-68]. This suppressive activity has been shown to be IL-10 [66] and TGF- $\beta$ dependent [65]. Additionally, $\mathrm{CD} 4+\mathrm{CD} 25+\mathrm{T}_{\text {reg }}$ cells partially promote differentiation of IL-10-secreting, contact-independent Trl-like cells in a contact-dependent manner [66].

In atopic individuals, the suppressive function of CD4+CD25+ T cells is diminished under certain conditions when compared with cells from nonatopic healthy controls $[69,70]$, and CD4+CD25+ cells from birch pollen-allergic patients exhibit an impaired suppression of birch pollen-stimulated CD4+CD25- cells [71]. In light of a putative increase in $\mathrm{CD} 4+\mathrm{CD} 25+\mathrm{T}_{\text {reg }}$ cells during SIT $[42,72]$, the relationship between inducible Tr1 cells 
and naturally occurring $\mathrm{T}_{\text {reg }}$ cells in induction of tolerance has to be further elucidated. Recent evidence suggests that after exposure to antigen in the periphery, CD4+CD25+ thymus-derived $\mathrm{T}_{\text {reg }}$ cells can terminally differentiate into $\mathrm{Tr} 1$ cells producing IL-10 and/or TGF$\beta$. On the other hand, Trl cells may just be another distinct subset of $\mathrm{T}_{\text {reg }}$ cells, with similar regulatory functions to $\mathrm{CD} 4+\mathrm{CD} 25+\mathrm{T}_{\text {reg }}$ cells $[73,74]$.

\section{T Helper 3 Cells}

Another subset of 'adaptive' $\mathrm{T}_{\text {reg }}$ cells, which is characterized by secretion of high amounts of TGF- $\beta$ but low levels of IL-4 and IL-10, has been designated as T helper 3 (Th3) cells $[75,76]$. This $\mathrm{T}_{\text {reg }}$ population was identified in experimental models of oral tolerance and has been investigated in several human autoimmune diseases including multiple sclerosis, arthritis and diabetes as well as in contact sensitivity and allergy [77]. The exact classification of Th3 cells is still debated. Immunologic features suggest that they may be of the same $T$ cell subset as Tr1 cells, the other subset of adaptive $\mathrm{T}_{\text {reg }}$ cells [78]. However, Th3 cells could also represent activated naturally occurring $\mathrm{T}_{\text {reg }}$ cells [79].

Faria and Weiner [77] see the amount of TGF- $\beta$ as a primary link between the distinct $\mathrm{T}_{\text {reg }}$ populations and proposed that Th3 cells - which secrete high levels of TGF- $\beta$ - may represent master regulators for the induction of $\mathrm{T}_{\text {reg }}$ cells in the periphery. Besides inhibiting the Th1- and Th2-promoting transcription factors T-bet and GATA-3 [80-82], TGF- $\beta$ has been shown to stimulate Foxp3 expression [83-85] and the expansion of $\mathrm{CD} 4+\mathrm{CD} 25+\mathrm{T}_{\text {reg }}$ cells in vivo [86-88]. In line with the latter findings, a recent study demonstrated that Th3 cells might mediate peripheral immune tolerance not only by direct immunosuppressive effects but also by the induction of CD4+CD25+ $\mathrm{T}_{\text {reg }}$ cells [89].
Finally, a specific role of Th3 cells in inducing oral tolerance has been assumed. TGF- $\beta$ can function as a switching and promotion factor for $\mathrm{B}$ cells towards the induction of IgA secretion [90, 91], and both increased TGF- $\beta$ serum levels and secretion of TGF- $\beta$-driven allergen-specific $\operatorname{Ig} A$ have been found in allergic patients treated by oral SIT $[15,92,93]$. Nevertheless, since other reports failed to show that $T_{\text {reg }}$ cells induced by oral SIT fulfill criteria typical of Th3 cells $[42,94,95]$, the precise function of Th3 cells in the regulatory network of immunotolerance remains to be determined.

\section{Summary}

ITA is characterized by an increased production of allergen-specific IgE antibodies and a predominant Th2 cell-driven cytokine pattern caused by an impaired balance of different $\mathrm{T}$ lymphocyte subsets. Therapeutic strategies for the treatment of ITA have to affect both the humoral and cellular disturbances. While utilization of anti-IgE antibodies presents a new, promising strategy to successfully inhibit the unwanted effects of enhanced $\operatorname{IgE}$ synthesis in ITA, it does not correct the underlying cellular pathomechanisms. SIT promotes the activation and expansion of different subsets of regulatory $\mathrm{T}$ cells, which actively regulate and rebalance the distribution of Thelper cells and their cytokine pattern. While the humoral and cellular mechanisms underlying this effect are only partially understood, carefully designed clinical studies of SIT-treated patients will help to further elucidate the immunological processes involved in achieving immune tolerance.

\section{References}

$\checkmark 1$ Cohen SG, Frankland AW, Dworetzky M: Noon and Freeman on prophylactic inoculation against hay fever. J Allergy Clin Immunol 2003;111:1142-1150.

-2 Bousquet J, Lockey R, Malling HJ: Allergen immunotherapy: therapeutic vaccines for allergic diseases. A WHO position paper. J Allergy Clin Immunol 1998;102:558-562.

3 Frew AJ: 25. Immunotherapy of allergic disease. J Allergy Clin Immunol 2003;111: S712-S719.

Allergy and Tolerance
4 Durham SR, Walker SM, Varga EM, Jacobson MR, O'Brien F, Noble W, Till SJ, Hamid QA, Nouri-Aria KT: Long-term clinical efficacy of grass-pollen immunotherapy. N Engl J Med 1999;341:468-475.

5 Coombs RRA, Gell PHG (eds): Clinical Aspects of Immunology. Oxford, Blackwell Scientific, 1975, p 761.

6 Romagnani S: T-cell subsets (Th1 versus Th2). Ann Allergy Asthma Immunol 2000; 85:9-18; quiz 18, 21.
7 Romagnani S: Lymphokine production by human T cells in disease states. Annu Rev Immunol 1994;12:227-257.

8 Mosmann TR, Sad S: The expanding universe of T-cell subsets: Th1, Th2 and more. Immunol Today 1996;17:138-146.

$\checkmark 9$ Rincon M, Anguita J, Nakamura T, Fikrig E, Flavell RA: Interleukin (IL)- 6 directs the differentiation of IL-4-producing CD4+ T cells. J Exp Med 1997;185:461-469. 
-10 Carballido JM, Faith A, Carballido-Perrig N, Blaser K: The intensity of T cell receptor engagement determines the cytokine pattern of human allergen-specific T helper cells. Eur J Immunol 1997;27:515-521.

-11 Van Ree R, Van Leeuwen WA, Dieges PH, Van Wijk RG, De Jong N, Brewczyski PZ, Kroon AM, Schilte PP, Tan KY, Simon-Licht IF, Roberts AM, Stapel SO, Aalberse RC: Measurement of IgE antibodies against purified grass pollen allergens (Lol p 1, 2, 3 and 5) during immunotherapy. Clin Exp Allergy 1997;27:68-74.

-12 Fennerty AG, Jones KP, Davies BH, Fifield R, Edwards J: Immunological changes associated with a successful outcome of pollen immunotherapy. Allergy 1988;43:415-419.

-13 Gehlhar K, Schlaak M, Becker W, Bufe A: Monitoring allergen immunotherapy of pollen-allergic patients: the ratio of allergenspecific IgG4 to IgG1 correlates with clinical outcome. Clin Exp Allergy 1999;29:497506.

14 Jutel M, Jaeger L, Suck R, Meyer H, Fiebig H, Cromwell O: Allergen-specific immunotherapy with recombinant grass pollen allergens. J Allergy Clin Immunol 2005;116:608613.

15 Jutel M, Akdis M, Budak F, Aebischer-Casaulta C, Wrzyszcz M, Blaser K, Akdis CA: IL10 and TGF-beta cooperate in the regulatory $\mathrm{T}$ cell response to mucosal allergens in normal immunity and specific immunotherapy. Eur J Immunol 2003;33:1205-1214.

16 Strait RT, Morris SC, Finkelman FD: IgGblocking antibodies inhibit IgE-mediated anaphylaxis in vivo through both antigen interception and Fc gamma RIIb cross-linking. J Clin Invest 2006;116:833-841.

17 Flicker S, Steinberger P, Norderhaug L, Sperr WR, Majlesi Y, Valent P, Kraft D, Valenta R: Conversion of grass pollen allergen-specific human IgE into a protective IgG(1) antibody. Eur J Immunol 2002;32:2156-2162.

-18 Wetterwald A, Skvaril F, Muller U, Blaser K: Isotypic and idiotypic characterization of anti-bee venom phospholipase A2 antibodies. Int Arch Allergy Appl Immunol 1985;77: 195-197.

19 van Neerven RJ, Wikborg T, Lund G, Jacobsen B, Brinch-Nielsen A, Arnved J, Ipsen H: Blocking antibodies induced by specific allergy vaccination prevent the activation of CD4+ T cells by inhibiting serum-IgE-facilitated allergen presentation. J Immunol 1999;163:2944-2952.

20 Peng ZK, Naclerio RM, Norman PS, Adkinson NF Jr: Quantitative IgE- and IgG-subclass responses during and after long-term ragweed immunotherapy. J Allergy Clin Immunol 1992;89:519-529.

21 Devey ME, Wilson DV, Wheeler AW: The IgG subclasses of antibodies to grass pollen allergens produced in hay fever patients during hyposensitization. Clin Allergy 1976;6: 227-236.
22 Creticos PS, Adkinson NF Jr, Kagey-Sobotka A, Proud D, Meier HL, Naclerio RM, Lichtenstein LM, Norman PS: Nasal challenge with ragweed pollen in hay fever patients. Effect of immunotherapy. J Clin Invest 1985; 76:2247-2253.

23 Rak S, Lowhagen O, Venge P: The effect of immunotherapy on bronchial hyperresponsiveness and eosinophil cationic protein in pollen-allergic patients. J Allergy Clin Immunol 1988;82:470-480.

24 Otsuka H, Mezawa A, Ohnishi M, Okubo K, Seki H, Okuda M: Changes in nasal metachromatic cells during allergen immunotherapy. Clin Exp Allergy 1991;21:115-119.

25 Flicker S, Valenta R: Renaissance of the blocking antibody concept in type I allergy. Int Arch Allergy Immunol 2003;132:13-24.

26 Wachholz PA, Durham SR: Mechanisms of immunotherapy: IgG revisited. Curr Opin Allergy Clin Immunol 2004;4:313-318.

27 Akdis CA, Blaser K: IL-10-induced anergy in peripheral $\mathrm{T}$ cell and reactivation by microenvironmental cytokines: two key steps in specific immunotherapy. FASEB J 1999;13: 603-609.

28 Norman PS: Immunotherapy. Prog Allergy 1982;32:318-346.

29 Birkner T, Rumpold H, Jarolim E, Ebner H, Breitenbach M, Skvaril F, Scheiner O, Kraft D: Evaluation of immunotherapy-induced changes in specific IgE, IgG and IgG subclasses in birch pollen allergic patients by means of immunoblotting. Correlation with clinical response. Allergy 1990;45:418-426.

30 Bodtger U, Ejrnaes AM, Hummelshoj L, Jacobi HH, Poulsen LK, Svenson M: Is immunotherapy-induced birch-pollen-specific IgG4 a marker for decreased allergen-specific sensitivity? Int Arch Allergy Immunol 2005;136:340-346.

31 Asai K, Kitaura J, Kawakami Y, Yamagata N, Tsai M, Carbone DP, Liu FT, Galli SJ, Kawakami T: Regulation of mast cell survival by IgE. Immunity 2001;14:791-800.

32 Kalesnikoff J, Huber M, Lam V, Damen JE, Zhang J, Siraganian RP, Krystal G: Monomeric IgE stimulates signaling pathways in mast cells that lead to cytokine production and cell survival. Immunity 2001;14:801811.

33 Kopp MV, Brauburger J, Riedinger F, Beischer D, Ihorst G, Kamin W, Zielen S, Bez, Friedrichs F, Von Berg A, Gerhold K, Hamelmann E, Hultsch, Kuehr J: The effect of anti$\mathrm{IgE}$ treatment on in vitro leukotriene release in children with seasonal allergic rhinitis. J Allergy Clin Immunol 2002;110:728-735.

34 Hamelmann E, Rolinck-Werninghaus C, Wahn U: From IgE to anti-IgE: where do we stand? Allergy 2002;57:983-994.

35 Jardieu PM, Fick RB Jr: IgE inhibition as a therapy for allergic disease. Int Arch Allergy Immunol 1999;118:112-115.

36 Chang TW: The pharmacological basis of anti-IgE therapy. Nat Biotechnol 2000;18: 157-162.
37 Durham SR, Ying S, Varney VA, Jacobson MR, Sudderick RM, Mackay IS, Kay AB, Hamid QA: Grass pollen immunotherapy inhibits allergen-induced infiltration of CD4+ $\mathrm{T}$ lymphocytes and eosinophils in the nasal mucosa and increases the number of cells expressing messenger RNA for interferongamma. J Allergy Clin Immunol 1996;97: 1356-1365.

-38 Ebner C, Siemann U, Bohle B, Willheim M, Wiedermann U, Schenk S, Klotz F, Ebner H, Kraft D, Scheiner O: Immunological changes during specific immunotherapy of grass pollen allergy: reduced lymphoproliferative responses to allergen and shift from $\mathrm{TH} 2$ to $\mathrm{TH} 1$ in T-cell clones specific for Phl p 1, a major grass pollen allergen. Clin Exp Allergy 1997;27:1007-1015.

39 Akdis M, Verhagen J, Taylor A, Karamloo F, Karagiannidis C, Crameri R, Thunberg S, Deniz G, Valenta R, Fiebig H, Kegel C, Disch $\mathrm{R}$, Schmidt-Weber CB, Blaser K, Akdis CA: Immune responses in healthy and allergic individuals are characterized by a fine balance between allergen-specific $\mathrm{T}$ regulatory 1 and T helper 2 cells. J Exp Med 2004;199: 1567-1575.

40 Cottrez F, Hurst SD, Coffman RL, Groux H: T regulatory cells 1 inhibit a Th2-specific response in vivo. J Immunol 2000;165:48484853.

41 Misra N, Bayry J, Lacroix-Desmazes S, Kazatchkine MD, Kaveri SV: Cutting edge: human CD4+CD25+ T cells restrain the maturation and antigen-presenting function of dendritic cells. J Immunol 2004;172:46764680 .

42 Bohle B, Kinaciyan T, Gerstmayr M, Radakovics A, Jahn-Schmid B, Ebner C: Sublingual immunotherapy induces IL-10-producing $\mathrm{T}$ regulatory cells, allergen-specific T-cell tolerance, and immune deviation. J Allergy Clin Immunol 2007;120:707-713.

43 Groux H, O’Garra A, Bigler M, Rouleau M, Antonenko S, de Vries JE, Roncarolo MG: A CD4+ T-cell subset inhibits antigen-specific $\mathrm{T}$-cell responses and prevents colitis. Nature 1997;389:737-742.

44 Levings MK, Sangregorio R, Galbiati F, Squadrone S, de Waal Malefyt R, Roncarolo MG: IFN-alpha and IL-10 induce the differentiation of human type $1 \mathrm{~T}$ regulatory cells. J Immunol 2001;166:5530-5539.

45 Li Y, Simons FE, Jay FT, HayGlass KT: Allergen-driven limiting dilution analysis of human IL-4 and IFN-gamma production in allergic rhinitis and clinically tolerant individuals. Int Immunol 1996;8:897-904.

46 Borish L, Aarons A, Rumbyrt J, Cvietusa P, Negri J, Wenzel S: Interleukin-10 regulation in normal subjects and patients with asthma. J Allergy Clin Immunol 1996;97:1288-1296. 
-47 Koning H, Neijens HJ, Baert MR, Oranje AP, Savelkoul HF: T cells subsets and cytokines in allergic and non-allergic children. 2 Analysis and IL-5 and IL-10 mRNA expression and protein production. Cytokine 1997; 9:427-436.

-48 Akdis CA, Blesken T, Akdis M, Wuthrich B, Blaser K: Role of interleukin 10 in specific immunotherapy. J Clin Invest 1998;102:98106.

-49 Nouri-Aria KT, Wachholz PA, Francis JN, Jacobson MR, Walker SM, Wilcock LK, Staple SQ, Aalberse RC, Till SJ, Durham SR: Grass pollen immunotherapy induces mucosal and peripheral IL-10 responses and blocking IgG activity. J Immunol 2004;172:32523259.

50 Groux H: An overview of regulatory T cells. Microbes Infect 2001;3:883-889.

51 Savolainen J, Jacobsen L, Valovirta E: Sublingual immunotherapy in children modulates allergen-induced in vitro expression of cytokine mRNA in PBMC. Allergy 2006;61: 1184-1190.

52 Akdis CA, Joss A, Akdis M, Blaser K: Mechanism of IL-10-induced T cell inactivation in allergic inflammation and normal response to allergens. Int Arch Allergy Immunol 2001; 124:180-182.

-53 Akdis CA, Joss A, Akdis M, Faith A, Blaser $\mathrm{K}$ : A molecular basis for $\mathrm{T}$ cell suppression by IL-10:CD28-associated IL-10 receptor inhibits CD28 tyrosine phosphorylation and phosphatidylinositol 3-kinase binding. FASEB J 2000;14:1666-1668.

54 Karagiannidis C, Akdis M, Holopainen P, Woolley NJ, Hense G, Ruckert B, Mantel PY, Menz G, Akdis CA, Blaser K, Schmidt-Weber CB: Glucocorticoids upregulate FOXP3 expression and regulatory $\mathrm{T}$ cells in asthma. J Allergy Clin Immunol 2004;114:14251433.

-55 Schandene L, Alonso-Vega C, Willems F, Gerard C, Delvaux A, Velu T, Devos R, de Boer M, Goldman M: B7/CD28-dependent IL-5 production by human resting $\mathrm{T}$ cells is inhibited by IL-10. J Immunol 1994;152:43684374.

-56 Marshall JS, Leal-Berumen I, Nielsen L, Glibetic $M$, Jordana M: Interleukin (IL)-10 inhibits long-term IL- 6 production but not preformed mediator release from rat peritoneal mast cells. J Clin Invest 1996;97:11221128.

-57 Nagato T, Kobayashi H, Yanai M, Sato K, Aoki N, Oikawa K, Kimura S, Abe Y, Celis E, Harabuchi Y, Tateno M: Functional analysis of birch pollen allergen Bet v 1-specific regulatory T cells. J Immunol 2007;178:11891198.

-58 Wood KJ, Sakaguchi S: Regulatory T cells in transplantation tolerance. Nat Rev Immunol 2003;3:199-210.
Sakaguchi S, Sakaguchi N, Asano M, Itoh M, Toda M: Immunologic self-tolerance maintained by activated T cells expressing IL-2 receptor alpha-chains (CD25). Breakdown of a single mechanism of self-tolerance causes various autoimmune diseases. J Immunol 1995;155:1151-1164.

60 Shevach EM: CD4+ CD25+ suppressor T cells: more questions than answers. Nat Rev Immunol 2002;2:389-400.

61 Read S, Powrie F: CD4(+) regulatory T cells. Curr Opin Immunol 2001;13:644-649.

62 Hori S, Nomura T, Sakaguchi S: Control of regulatory $\mathrm{T}$ cell development by the transcription factor Foxp3. Science 2003;299: 1057-1061.

63 Khattri R, Cox T, Yasayko SA, Ramsdell F: An essential role for Scurfin in CD4+CD25+ T regulatory cells. Nat Immunol 2003;4:337342.

64 Fontenot JD, Gavin MA, Rudensky AY: Foxp3 programs the development and function of CD4+CD25+ regulatory T cells. Nat Immunol 2003;4:330-336.

65 Jonuleit H, Schmitt E, Kakirman H, Stassen M, Knop J, Enk AH: Infectious tolerance: human CD25(+) regulatory T cells convey suppressor activity to conventional CD4(+) T helper cells. J Exp Med 2002;196:255-260.

66 Dieckmann D, Bruett CH, Ploettner H, Lutz MB, Schuler G: Human CD4(+)CD25(+) regulatory, contact-dependent $\mathrm{T}$ cells induce interleukin 10-producing, contact-independent type 1-like regulatory T cells [corrected]. J Exp Med 2002;196:247-253.

67 Qin S, Cobbold SP, Pope H, Elliott J, Kioussis $\mathrm{D}$, Davies J, Waldmann H: 'Infectious' transplantation tolerance. Science 1993;259:974977.

68 Modigliani Y, Bandeira A, Coutinho A: A model for developmentally acquired thymus-dependent tolerance to central and peripheral antigens. Immunol Rev 1996;149: 155-120.

69 Bellinghausen I, Klostermann B, Knop J, Saloga J: Human CD4+CD25+ T cells derived from the majority of atopic donors are able to suppress $\mathrm{TH} 1$ and $\mathrm{TH} 2$ cytokine production. J Allergy Clin Immunol 2003;111:862868.

70 Bellinghausen I, Konig B, Bottcher I, Knop J, Saloga J: Regulatory activity of human CD4 CD25 T cells depends on allergen concentration, type of allergen and atopy status of the donor. Immunology 2005;116:103-111.

71 Thunberg S, Akdis M, Akdis CA, Gronneberg R, Malmstrom V, Trollmo C, van Hage $\mathrm{M}$, Gafvelin G: Immune regulation by CD4+CD25+ T cells and interleukin-10 in birch pollen-allergic patients and non-allergic controls. Clin Exp Allergy 2007;37:11271136.
Mamessier E, Birnbaum J, Dupuy P, Vervloet D, Magnan A: Ultra-rush venom immunotherapy induces differential $\mathrm{T}$ cell activation and regulatory patterns according to the severity of allergy. Clin Exp Allergy 2006;36: 704-713.

73 Levings MK, Sangregorio R, Sartirana C, Moschin AL, Battaglia $M$, Orban PC, Roncarolo MG: Human CD25+CD4+ T suppressor cell clones produce transforming growth factor beta, but not interleukin 10, and are distinct from type $1 \mathrm{~T}$ regulatory cells. J Exp Med 2002;196:1335-1346.

74 Roncarolo MG, Levings MK, Traversari C: Differentiation of $\mathrm{T}$ regulatory cells by immature dendritic cells. J Exp Med 2001;193: F5-F9.

75 Chen Y, Kuchroo VK, Inobe J, Hafler DA, Weiner HL: Regulatory T cell clones induced by oral tolerance: suppression of autoimmune encephalomyelitis. Science 1994;265: 1237-1240.

76 Weiner HL, Friedman A, Miller A, Khoury SJ, al-Sabbagh A, Santos L, Sayegh M, Nussenblatt RB, Trentham DE, Hafler DA: Oral tolerance: immunologic mechanisms and treatment of animal and human organ-specific autoimmune diseases by oral administration of autoantigens. Annu Rev Immunol 1994;12:809-837.

77 Faria AM, Weiner HL: Oral tolerance. Immunol Rev 2005;206:232-259.

78 Verhagen J, Blaser K, Akdis CA, Akdis M: Mechanisms of allergen-specific immunotherapy: T-regulatory cells and more. Immunol Allergy Clin North Am 2006;26:207-231, vi.

79 Wan YY, Flavell RA: 'Yin-Yang' functions of transforming growth factor-beta and T regulatory cells in immune regulation. Immunol Rev 2007;220:199-213.

80 Gorelik L, Constant S, Flavell RA: Mechanism of transforming growth factor beta-induced inhibition of T helper type 1 differentiation. J Exp Med 2002;195:1499-1505.

81 Gorelik L, Fields PE, Flavell RA: Cutting edge: TGF-beta inhibits Th type 2 development through inhibition of GATA-3 expression. J Immunol 2000; 165:4773-4777.

82 Heath VL, Murphy EE, Crain C, Tomlinson MG, O'Garra A: TGF-betal down-regulates Th2 development and results in decreased IL-4-induced STAT6 activation and GATA-3 expression. Eur J Immunol 2000;30:26392649.

83 Chen W, Jin W, Hardegen N, Lei KJ, Li L, Marinos N, McGrady G, Wahl SM: Conversion of peripheral CD $4+\mathrm{CD} 25$ - naive T cells to $\mathrm{CD} 4+\mathrm{CD} 25+$ regulatory $\mathrm{T}$ cells by $\mathrm{TGF}-$ beta induction of transcription factor Foxp3. J Exp Med 2003;198:1875-1886.

84 Fantini MC, Becker C, Monteleone G, Pallone F, Galle PR, Neurath MF: Cutting edge: TGF-beta induces a regulatory phenotype in CD4+CD25- T cells through Foxp3 induction and down-regulation of Smad7. J Immunol 2004;172:5149-5153. 
85 Marie JC, Letterio JJ, Gavin M, Rudensky AY: TGF-betal maintains suppressor function and Foxp3 expression in CD4+CD25+ regulatory T cells. J Exp Med 2005;201:10611067.

-86 Peng Y, Laouar Y, Li MO, Green EA, Flavell RA: TGF-beta regulates in vivo expansion of Foxp3-expressing CD4+CD25+ regulatory $T$ cells responsible for protection against diabetes. Proc Natl Acad Sci USA 2004;101: 4572-4577.

-87 Huber S, Schramm C, Lehr HA, Mann A, Schmitt S, Becker C, Protschka M, Galle PR, Neurath MF, Blessing M: Cutting edge: TGFbeta signaling is required for the in vivo expansion and immunosuppressive capacity of regulatory CD4+CD25+ T cells. J Immunol 2004;173:6526-6531.
8 Huber S, Schramm C: TGF-beta and CD4+CD25+ regulatory T cells. Front Biosci 2006;11:1014-1023.

89 Carrier Y, Yuan J, Kuchroo VK, Weiner HL: Th3 cells in peripheral tolerance. 1. Induction of Foxp3-positive regulatory $\mathrm{T}$ cells by Th3 cells derived from TGF-beta T celltransgenic mice. J Immunol 2007;178:179185.

90 Cazac BB, Roes J: TGF-beta receptor controls $\mathrm{B}$ cell responsiveness and induction of $\operatorname{Ig} \mathrm{A}$ in vivo. Immunity 2000;13:443-451.

91 Letterio JJ, Roberts AB: Regulation of immune responses by TGF-beta. Annu Rev Immunol 1998;16:137-161.

92 Taudorf E: Oral immunotherapy of adults with allergic rhinoconjunctivitis. Clinical effects in birch and grass pollinosis. Dan Med Bull 1992;39:542-560.
Ariano R, Panzani RC, Augeri G: Efficacy and safety of oral immunotherapy in respiratory allergy to Parietaria judaica pollen. A double-blind study. J Investig Allergol Clin Immunol 1998;8:155-160.

94 Fanta C, Bohle B, Hirt W, Siemann U, Horak F, Kraft D, Ebner H, Ebner C: Systemic immunological changes induced by administration of grass pollen allergens via the oral mucosa during sublingual immunotherapy. Int Arch Allergy Immunol 1999;120:218224.

95 Cosmi L, Santarlasci V, Angeli R, Liotta F, Maggi L, Frosali F, Rossi O, Falagiani P, Riva G, Romagnani S, Annunziato F, Maggi E: Sublingual immunotherapy with Dermatophagoides monomeric allergoid downregulates allergen-specific immunoglobulin E and increases both interferon-gamma- and interleukin-10-production. Clin Exp Allergy 2006;36:261-272. 